\title{
Association between Field of Work, Years of Service, and Sickness Absenteeism in Public Administration
}

\begin{abstract}
Jernej BUZETI
University of Ljubljana, Faculty of Public Administration, Gosarjeva ulica 5, 1000 Ljubljana, Slovenia, jernej.buzeti@ fu.uni-lj.si
\end{abstract}

\begin{abstract}
Background and Purpose: Statistics of sickness absenteeism in public administration in Slovenia is considerably higher ( $7.1 \%$ in 2018) than the percentage that applies for the whole of Slovenia (4.5\% in 2018). The data also shows a similar pattern in the public sector in other countries. According to that, the main purpose of our research is to investigate the connection between fields of work, years of service, and sickness absenteeism in public administration in Slovenia.

Methodology: Research data was collected with the help of an online questionnaire, which was designed for empirical research and consisted of several sets of questions. The collected data was processed using the SPSS statistical program.

Results: The research was conducted in 2015 in public administration institutions, and 3,220 employees from public administration were included in our research sample. The results of the research show that there is a statistically significant connection between sickness absenteeism in public administration and years of service and the field of work of employees in public administration.

Conclusion: The survey helps us to understand the connection between sickness absenteeism and years of service and field of work of employees in public administration. With regard to the results, it would be reasonable to adopt measures focused on groups of employees in public administration (older employees with a greater length of service, employed officials and professional-technical public employees) where sickness absence may be reduced. Sickness absenteeism in these groups of employees could be reduced by providing employees better leadership and conditions for satisfaction in the workplace.
\end{abstract}

Keywords: sickness absenteeism, public administration, years of service, field of work

\section{Introduction}

An organisation is a social formation of employees, and in every social situation there are daily relationships between employees and other factors in the working environment. Employees also react differently to social situations in the working environment: some of them adapt to factors of influence (poor relationships with managers, increased workload, stress) and accept them, while others can face difficulties. The consequences of the latter can often also be reflected in sickness absenteeism, in other words the temporary absence of employees from work because of sickness or injury, or because they are caring for family members (Buzeti, Bilban and Stare, 2015).

Employees may be absent from work due to annual leave, their own health problems, health problems of family members, training, etc. The latter indicates that absenteeism is a complex and multidimensional segment that requires accurate and correct discourse. This article focuses on the part of employee absenteeism, as demonstrated by sickness absenteeism. In the opinion of Toth (1999, p. 20), we understand the concept of sickness absenteeism as meaning lost working days, or time in which an employ-

Received: October 9, 2019; revised: January 17, 2020; accepted: February 7, 2020 
ee is temporarily unable to work because of sickness or injury.

The focus on studying the connection between field of work, years of service, and sickness absenteeism in public administration is motivated particularly by the fact that it is possible to find, on the basis of statistical data of the National Institute for Public Health (hereinafter as: NIJZ), that the share of sickness absenteeism in public administration is considerably higher than the percentage that applies for all sickness absenteeism in Slovenia. Sickness absenteeism is rather high in public organisations compared to private organisations (Løkke and Krøtel, 2019; NIJZ, 2019; Løkke, 2014; Coffey, Dugdill and Tattersall, 2009). In Slovenia, the duration of an individual case of sickness absence in the private sector is longer than in the public sector; nevertheless, individual employees in the public sector take sick leave more often in a year, which consequently leads to more days of sick leave per employee (NIJZ, 2019). The next reason for studying is connected to the fact that we were interested in whether years of service in the organisation of employment and the field of work (work position), have influence on sickness absenteeism.

Based on NIJZ data (2014-2018), we found that the greatest percentage of lost calendar days in public administration due to sickness absenteeism in the period compared, was recorded in 2018 , i.e. $7.1 \%$, and the lowest percentage in 2014 , i.e. $6 \%$. It is interesting, however, that since 2014, the number of lost calendar days has been constantly increasing in public administration in Slovenia.

There are many different factors that influence sickness absenteeism. With the purpose to discover whether there is association between sickness absenteeism in public administration, years of service by public employees, and the field of work (work position), we made a decision to study the state, and check the connections, with the help of obtained research data and its analysis.

The main purpose of the article is to analyse the connection between sickness absenteeism in public administration, years of service, and the field of work (work position) of employees in public administration, and to present the aspect of sensibility of taking into consideration years of service and work position of employees in the context of sickness absenteeism in public administration. We have decided to analyse the two variables, i.e. the years of service and field of work, in relation to sickness absence, because we were interested in whether in Slovenia there is any association between the years of service and sickness absenteeism in public administration like it is the case in some other studies (Hum Wee et al., 2019; Løkke Nielsen, 2008). We found no research on how the field of work is associated with sickness absenteeism in public administration; therefore we wanted to explore the association ourselves.

\section{Review of theory}

Absenteeism is one of the oldest and most researched phenomena in the history of human resource management and organisational behaviour (Forte, 2017; Patton and Johns, 2012). Absenteeism is a complex and multifactorial phenomenon, influenced by various interrelated factors (Nguyen, Groth and Johnson, 2013; Elshout et al., 2013). Definitions of sickness absenteeism vary (Schmid et al., 2017; Nielsen \& Daniels, 2016; Shapira-Lishchinsky \& Raftar-Ozery, 2016; Fitzgerald et al., 2016; Schouten, 2016; Buzeti et al., 2016, Halbesleben et al., 2014; Løkke, Eskildsen and Jensen, 2007;). Sickness absenteeism was defined as temporary paid leave from work due to any (i.e. work-related and non-work-related) injury or illness (Schouten, 2016, p. 302). In our article, sickness absenteeism is treated as all those cases "where employees are absent from work due to personal illness or injury or to care for family members, their absence is treated as temporary from a temporal point of view" (Buzeti et al., 2016, p. 24).

Sickness absenteeism may be attributable to many different factors, including lifestyle factors, demographic and socio-economic characteristics, etc. (Fitzgerald et al., 2016). An individual may have greater influence on some factors, and can prevent or limit them, whereas their influence on some factors is smaller or cannot be defined at all. If we take into account that for the occurrence of sickness absenteeism, a person and work are needed, it is sensible to define the influence of certain demographic characteristics, which are linked to an individual in a working environment, on sickness absenteeism. If we take into consideration characteristics that are connected to an individual, we discover that it is possible to find, in association with sickness absenteeism, that (Hum Wee et al., 2019; Lyszczarz, 2019; Buzeti, 2015; Løkke, 2014; De Paola, Scoppa and Pupo, 2014; Løkke Nielsen, 2008, pp. 1333-1335; Løkke, Eskildsen and Jensen, 2007, pp. 20 28; Allebeck and Mastakaasa, 2004; Ones, Viswiesvaran and Schmidt, 2003, pp. 20-21; Evans and Palmer, 2000, pp. 20-23; Rhodes and Steers 1990) years of service, age, gender, and education, are important factors affecting sickness absenteeism.

Considering the fact that we are focused on the connection between years of service, field of work (work position), and sickness absenteeism in our article, we have found that the research shows that years of service, or the influence of a period of employment on sickness absenteeism, can sometimes be detected, while in other cases it cannot be. Løkke Nielsen (2008, p. 1334) presents a general thesis that if sickness absenteeism is the result of dissatisfaction with the work situation, all those employees with more years of service are less absent from work compared to those with fewer years of service. Contrary to the previous justification, it is also possible to see another perspective, i.e. that employees with more years of 
service may face fewer career opportunities and fewer possibilities for employment in another organisation. The latter may lead to dissatisfaction, and a consequence of that can also be absence from work. In the framework of her research, Løkke Nielsen (2008) did not confirm the influence of years of service on sickness absenteeism.

In the research about sickness absenteeism in the Italian public sector, it was established that "the probability of being absent increases with tenure" (De Paola, Scoppa and Pupo, 2014). On the contrary, Winkelmann (1996) discovered in his research, and confirmed that there is a connection between high seniority and low absenteeism. In one of her researches, Løkke (2014) confirmed the connection between sickness absenteeism and years of service, but the results were not the same in both models that were compared. In the first model, she discovered that the probability for sickness absenteeism is smaller for up to 10 years of service, and then it increases. In the second model, she discovered that the probability for sickness absenteeism decreases with more years of service. Overall, seniority influences sickness absenteeism, both in terms of the quality of the person-environment fit, and also in terms of end-of-career frustration (Løkke, 2014). In the research of Rosenblatt, Shapira-Lishchinsky and Shiron (2010), "although seniority was not directly related to absence, the results showed that in high levels of seniority ( 5 years and above), the negative relationship between a caring ethical climate and absence frequency was weaker than in lower levels of seniority ( 3 years and below)."

In the framework of understanding the connection between the field of work and sickness absenteeism, it is reasonable to consider that employees with leading positions are absent from work less often than those employees who do not have leading positions (Løkke Nielsen, 2008; Buzeti, 2015). Kristensen and others (Løkke Nielsen, 2008, p. 1336) explain that it is possible to detect, in case absence from work of the leading personnel has been high, that other employees are also more absent from work. Often, employees in the leading fields of work and related leading work positions, are better valued. It is therefore reasonable to understand the following working position, also in relation to the salary and, as the research shows, "workers are less absent if they enjoy a higher salary, a higher relative salary, and are employed at a higher hierarchical level" (Pfeifer, 2010, p. 69). The research by King et al. (2013) shows that managers were less absent from work than professional workers. Their research results show that the lowest level of sickness absence in the past year is attributable to managerial staff. Shorter sick leave (up to 14 days) was most commonly used by professional workers. Employees who perform routine and repetitive (the same) jobs with a low level of autonomy and responsibility, and a low possibility to make and create decisions, are more inclined to be absent from work (Evans and Palmer, 2000, p.25). As a result, from the conducted research, we can see that seniority and field of work (work position) are important factors, and correlate in understanding and interpreting the phenomenon of sickness absenteeism.

\section{Methods}

\subsection{Procedure and Participants}

Prior to collecting data, we tested our questionnaire among employees in public administration, and in accordance with our findings in the process of evaluation of its reliability and validity, we adapted it correspondingly. We decided on the next step, because we wanted to (1) prepare a quality and useful questionnaire, and (2) check the initially designed questions/statements. When testing the originally designed questionnaire, it was discovered that there was ambiguity in some questions and statements, which was removed from the final version of the questionnaire.

Research data was collected with the help of an online questionnaire, which was created with the $1 \mathrm{ka}$ online tool. We included employees of public administration in our research, which is hereby treated as all those organisations that are part of the process of decision-making about public matters, or participate in the management of public matters. Our research therefore included employees of the Ministries and the authorities in their composition, levels of government, administrative units, (city) municipalities, and holders of public authorisations. Holders of public authorisations are natural and legal persons, and among those that we classify as public administration are public agencies, public funds, and some public institutions (e.g. Pension and Disability Insurance Institute of Slovenia, Employment Service of Slovenia, Social Work Centres, etc.), and chambers with compulsory membership (Tičar and Rakar, 2011).

We carried out research in Slovenian public administration that took place in February 2015. In our research, we gathered answers/data from 3,220 respondents in public administration, which represents an $8.1 \%$ share of the entire population of employees in public administration. Table 1 shows the distribution of employees by the type of organisation and number of employees in public administration in Slovenia.

The sample in our research included $69.7 \%$ of employees in public administration, $11.1 \%$ of employees in local self-government, and $19 \%$ of employees of holders of public authorisations. The largest share in the structure of the sample from our research is represented by officials (58.9\%), professional-technical personnel $(26.7 \%)$, and a little less than a tenth of respondents $(9.1 \%)$ are officials in leading positions (heads) of organisational units, with up to 30 direct subordinates. The remaining fields of work in the entire structure of the sample represent shares that are smaller than $2 \%$. A little more than three quarters of those 
sampled were female (76.1\%) and nearly a third (23.9\%) were male. The majority of respondents or employees who cooperated in this research were 35 to 44 years old $(36.9 \%)$ or 45 to 54 years old $(34.7 \%)$.

In this article, we treat officials as those public employees who perform public tasks for authorities. Public tasks for authorities are tasks that are directly connected with enforcement of authority, or protection of the public interest. Public officials who perform supporting tasks are professional-technical public employees. Supporting tasks are tasks in the field of personnel management and material-financial operation, financial and similar tasks, and other tasks that must be performed for the smooth op- eration of public tasks of the authority (ZJU, Article 23). We treat officials in leading positions in this article as all those (ZJU, Article 80) who perform authorisations for leading, coordinating, and organising work. According to the law (ZJU, Article 80), the positions are: general director, secretary general and heads of organisational units at the ministries, director and heads of organisational units in authorities within the ministry, head of administrative units, heads of organisational units in administrative units, director and heads of organisational units in levels of government, director and heads of organisational units in the management of local communities.

Table 1: Distribution of employees by the type of organisation and number of employees in public administration in Slovenia.

\begin{tabular}{|c|c|c|c|c|}
\hline \multirow{2}{*}{$\begin{array}{c}\text { Type of public administration } \\
\text { organisation }\end{array}$} & \multicolumn{2}{|c|}{ Participants (sample) } & \multicolumn{2}{|c|}{$\begin{array}{l}\text { Number of employees in public } \\
\text { administration in Slovenia }\end{array}$} \\
\hline & $\mathrm{f}$ & $\%$ & $\mathrm{f}$ & $\%$ \\
\hline State administration & 2,230 & $69.7 \%$ & 29,295 & $73.7 \%$ \\
\hline Local administration & 354 & $11.1 \%$ & 4,825 & $12.1 \%$ \\
\hline Holders of public authorities & 609 & $19.2 \%$ & 5,603 & $14.1 \%$ \\
\hline Total public administration & 3,200 & & 39,723 & \\
\hline
\end{tabular}

\subsection{Measures}

SA questionnaire was designed for the empirical research, and consisted of several sets of questions (see appendix). To collect data about the connection between field of work, years of service, and sickness absenteeism in public administration, two sets of questions were designed for the questionnaire, i.e.:

- the first set of questions ("General demographic data"); comprises six short questions of open and closed type, which refer to the socio-demographic characteristics of the respondents, such as organisation of employment, their field of work, gender, year of birth (age), level of education, years of service in the organisation of current employment.

- the second set of questions ("Sickness absence"); addresses sickness absenteeism. There are six short questions of open and closed type, which check the existence of sickness absences from work in the past 12 months, reasons for them, and frequency of sickness absences from work in the past 12 months, expressed as the number of days and the number of sets of absences ("how many times"). The first four short open questions verified the frequency of absence from work in the last 12 months, expressed in the number of days and the number of absences, as well as the reasons for those absences. We used the methodology used by Ybema et al. (2010). The approach has also been used in other recent studies to determine the correlation of health absenteeism with other factors. Questions five and six in the second set of questions are the closed type of questions ("Yes" or "No"). "Yes", in relation to question five, means "Yes, I have been absent, despite was being able to carry out work tasks«. "No" means "No, I have not been absent, despite was being able to carry out work tasks". "Yes", in relation to question six, means "Yes, I have performed my work tasks despite being ill or injured". "No" means "No, I have not performed my work tasks due to being ill or injured ".

As mentioned above, the survey was carried out in February 2015, but the percentage of lost calendar days in public administration in Slovenia due to sickness absenteeism has been increasing every year since 2014. Although our survey was conducted in 2015, we can conclude from the NIJZ (2019) statistical data, that the percentage of sickness absenteeism in public administration is increasing year by year; therefore, we consider that the results of the research are relevant and important, even today, for the understanding of the sickness absenteeism of employees in the Slovenian public administration. 


\section{Results}

\subsection{Connection between Field of Work, Years of Service, and Sickness Absenteeism in Public Administration}

In the context of establishing whether seniority of employees in public administration in the current employment organisation affects sickness absenteeism in public administration, we created four classes of the years of service, variable for the purpose of analysis, i.e.:

- first class: up to 10 years of service in the organisation;

- second class: 10 to 19 years of service in the organisation;

- third class: 20 to 29 years of service in the organisation;

- fourth class: 30 years and more of service in the organisation;
Based on the analysis of the research results, it was discovered that the respondents characteristically differ in the overall length of duration of sickness absenteeism in the past 12 months, according to the years of service (Table 2) $\left(\chi^{2}=39.04 ; p<0.01\right)$. Respondents with up to 10 years of service were absent from work for the least number of days (8.05 days), while respondents with over 30 years of service were absent from work for the largest number of days (10.27 days). Respondents with 10 to 19 years of service were slightly less absent from work than the respondents with over 30 years of service (9.71 days), and respondents with 20 to 29 years of service were absent from work even less ( 9.35 days).

Based on the results from Table 2, we can see that the existence of statistically significant differences by years of service is also shown in the length of sickness absenteeism due to caring for or illness of a dependant family member $\left(\chi^{2}=141.94 ; p<0.01\right)$, with a rule that length of sickness absenteeism decreases while seniority increases. The length of sickness absenteeism due to their own illness or injury increases with years of service; however, differences between groups are not statistically significant $\left(\chi^{2}=3.58 ; \mathrm{p}\right.$ $>0.05)$.

Table 2: Descriptive statistics of the number of days of absence, and the results of Kruskal-Wallis test by years of service and by an individual reason for temporary absence.

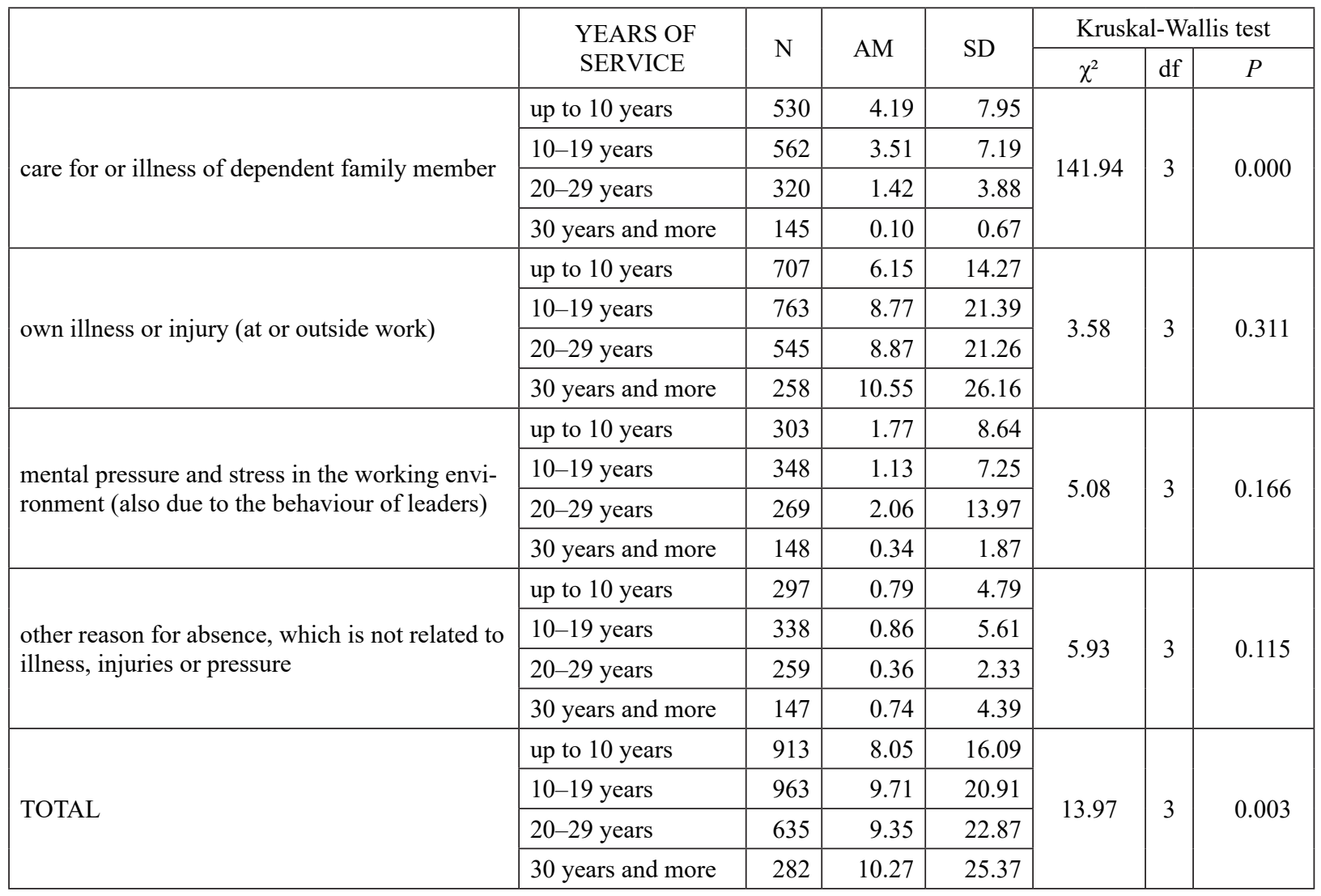

$\mathrm{N}$ - number of answers; AM - arithmetic mean; SD - standard deviation; df - degrees of freedom; $\mathrm{p}$ - level of statistical significance 
Table 3: A series of post-hoc tests (Mann-Whitney U test) between pairs of classes of years of service, in relation to the number of days of temporary absence

\begin{tabular}{|c|c|c|c|c|c|c|c|c|c|c|c|}
\hline \multicolumn{2}{|c|}{$\begin{array}{l}\text { up to } 10 \text { years - } \\
10-19 \text { years }\end{array}$} & \multicolumn{2}{|c|}{$\begin{array}{l}\text { up to } 10 \text { years - } \\
20-29 \text { years }\end{array}$} & \multicolumn{2}{|c|}{$\begin{array}{c}\text { up to } 10 \text { years }-30 \\
\text { years and more }\end{array}$} & \multicolumn{2}{|c|}{$\begin{array}{c}10-19 \text { years }- \\
20-29 \text { years }\end{array}$} & \multicolumn{2}{|c|}{$\begin{array}{l}10-19 \text { years }-30 \\
\text { years and more }\end{array}$} & \multicolumn{2}{|c|}{$\begin{array}{c}20-29 \text { years }-30 \\
\text { years and more }\end{array}$} \\
\hline $\mathrm{U}$ & $p$ & $\mathrm{U}$ & $p$ & $\mathrm{U}$ & $p$ & $\mathrm{U}$ & $p$ & $\mathrm{U}$ & $p$ & $\mathrm{U}$ & $P$ \\
\hline \multicolumn{12}{|c|}{ care for or illness of dependent family member } \\
\hline 139968 & 0.061 & 61278 & 0.000 & 20432 & 0.000 & 70143 & 0.000 & 23796 & 0.000 & 18507 & 0.000 \\
\hline \multicolumn{12}{|c|}{ TOTAL } \\
\hline 433468 & 0.590 & 276196 & 0.101 & 113569 & 0.002 & 288065 & 0.042 & 119049 & 0.001 & 83308 & 0.074 \\
\hline
\end{tabular}

$\mathrm{U}$ - value of Mann-Whitney test; $\mathrm{p}$ - statistical significance

A series of post-hoc tests (Table 3 ) shows that respondents differ from each other by their seniority statistically significantly, in relation to days of sickness absence in the last 12 months due to caring for or illness of a dependent family member, where the only exceptions are groups of respondents with up to 10 years of service and between 10 and 19 years of service, where statistically significant differences could not be confirmed. By the total length of sickness absence in the past 12 months (Table 3 ), there are statistically significant differences between respondents with the fewest years of service (up to 10 years and between 10 and 19 years), and those with the most years of service (30 years and more), while at the same time, there is a statistical difference between groups of respondents with 10 to 19 years of service and 20 to 29 years of service.

Respondents statistically significantly differ also in the number of total sets of sickness absence (Table 4) in the last 12 months $\left(\chi^{2}=61.81 ; p<0.01\right)$, according to their years of service in the current organisation of employment. Respondents with up to 10 years of service were most notably absent from work (1.8 times), but by increasing the years of service, the number of sets of sickness absence decreases; respondents with over 30 years of service were absent from work more than half as many times ( 0.8 times) than those with the fewest years of service.

Differences between the number of sets of sickness absence due to caring for or illness of a dependent family member $\left(\chi^{2}=146.11 ; \mathrm{p}<0.01\right)$ and their own illness or injury $\left(\chi^{2}=20.43 ; p<0.01\right)$, are also statistically significant (Table 4), where the number of sets of absences decreases by the increasing years of service. The existence of statistically significant differences between groups by years of service also shows in other reasons for absence, which are not connected to illness, injuries, or pressure $\left(\chi^{2}=9.4\right.$; $\mathrm{p}<0.05)$, due to which respondents with 10 to 19 years of service are absent the most times ( 0.2 times), whereas respondents with 20 to 29 years are absent the fewest times (0.05 times).
Next, we noted that (Table 5) the respondents statistically significantly differ from each other by their years of service in the total number of sets of sickness absence in the past 12 months, and at the same time in absence due to caring for or illness of a dependent family member, except for the groups of respondents with up to 10 years of service and between 10 and 19 years of service, where statistically significant differences could not be confirmed. By the number of sets of sickness absence in the past 12 months due to their own illness or injury, there are statistically significant differences between respondents with the most years of service (30 years or more) and the remaining groups of respondents, while at the same time, there is a statistical difference between groups of respondents with the fewest years of service (up to 10 years) and from 20 to 29 years of service.

For the number of sets of sickness absence due to other reasons for absence, there are statistically significant differences (Table 5) only between respondents who have up to 10 years of service and respondents who have between 20 to 29 years of service, while at the same time, there are statistically significant differences between the first group, and respondents with the most years of service (30 years or more).

Based on the results of the research about the connection between years of service with sickness absenteeism, we noticed $a$ trend of less frequent (number of sets) sickness absence by increasing years of service, which mostly shows in sickness absence due to caring for or illness of a dependent family member, and due to their own illness or injury. On the other hand, the total number of days of sickness absence increases with increasing years of service, which is mostly true of absences from work due to their own illness or injury, although the number of days of sickness absence due to caring for or illness of a dependent family member decreases with increasing years of service. 
Table 4: Descriptive statistics of the number of sets of sickness absence and the results of Kruskal-Wallis test by years of service and by individual reason for sickness absence

\begin{tabular}{|c|c|c|c|c|c|c|c|}
\hline & \multirow{2}{*}{$\begin{array}{l}\text { YEARS OF } \\
\text { SERVICE }\end{array}$} & \multirow{2}{*}{$\mathrm{N}$} & \multirow{2}{*}{$\mathrm{AM}$} & \multirow{2}{*}{$\mathrm{SD}$} & \multicolumn{3}{|c|}{ Kruskal-Wallis test } \\
\hline & & & & & $\chi^{2}$ & df & $P$ \\
\hline \multirow{4}{*}{ care for or illness of dependent family member } & up to 10 years & 526 & 1.51 & 2.67 & \multirow{4}{*}{146.11} & \multirow{4}{*}{3} & \multirow{4}{*}{0.000} \\
\hline & $10-19$ years & 561 & 1.26 & 2.04 & & & \\
\hline & 20-29 years & 316 & 0.52 & 1.35 & & & \\
\hline & 30 years and more & 145 & 0.09 & 0.66 & & & \\
\hline \multirow{4}{*}{ own illness or injury (at or outside work) } & up to 10 years & 700 & 1.04 & 1.23 & \multirow{4}{*}{20.43} & \multirow{4}{*}{3} & \multirow{4}{*}{0.000} \\
\hline & $10-19$ years & 756 & 1.01 & 1.51 & & & \\
\hline & $20-29$ years & 539 & 0.97 & 1.32 & & & \\
\hline & 30 years and more & 253 & 0.74 & 1.13 & & & \\
\hline \multirow{4}{*}{$\begin{array}{l}\text { mental pressure and stress in the working envi- } \\
\text { ronment (also due to the behaviour of leaders) }\end{array}$} & up to 10 years & 303 & 0.20 & 1.00 & \multirow{4}{*}{4.85} & \multirow{4}{*}{3} & \multirow{4}{*}{0.183} \\
\hline & 10-19 years & 348 & 0.16 & 0.61 & & & \\
\hline & $20-29$ years & 268 & 0.15 & 0.62 & & & \\
\hline & 30 years and more & 148 & 0.09 & 0.46 & & & \\
\hline \multirow{4}{*}{$\begin{array}{l}\text { other reason for absence, which is not related } \\
\text { to illness, injuries, or pressure }\end{array}$} & up to 10 years & 298 & 0.17 & 0.66 & \multirow{4}{*}{9.40} & \multirow{4}{*}{3} & \multirow{4}{*}{0.024} \\
\hline & 10-19 years & 338 & 0.21 & 1.07 & & & \\
\hline & 20-29 years & 257 & 0.05 & 0.28 & & & \\
\hline & 30 years and more & 146 & 0.10 & 0.59 & & & \\
\hline \multirow{4}{*}{ TOTAL } & up to 10 years & 912 & 1.79 & 2.68 & \multirow{4}{*}{61.81} & \multirow{4}{*}{3} & \multirow{4}{*}{0.000} \\
\hline & 10-19 years & 961 & 1.66 & 2.46 & & & \\
\hline & $20-29$ years & 631 & 1.17 & 1.79 & & & \\
\hline & 30 years and more & 278 & 0.82 & 1.46 & & & \\
\hline
\end{tabular}

$\mathrm{N}$ - number of answers; AM - arithmetic mean; SD - standard deviation; df - degrees of freedom; $\mathrm{p}$ - level of statistical significance

Table 5: A series of post-hoc tests (Mann-Whitney U test) between pairs of classes of years of service, in relation to the number of sets of absence

\begin{tabular}{|c|c|c|c|c|c|c|c|c|c|c|c|}
\hline \multicolumn{2}{|c|}{$\begin{array}{l}\text { up to } 34 \text { years - } \\
35-44 \text { years }\end{array}$} & \multicolumn{2}{|c|}{$\begin{array}{c}\text { up to } 34 \text { years - } \\
45-54 \text { years }\end{array}$} & \multicolumn{2}{|c|}{$\begin{array}{l}\text { up to } 34 \text { years - } \\
55 \text { years and more }\end{array}$} & \multicolumn{2}{|c|}{$\begin{array}{c}35-44 \text { years - } \\
45-54 \text { years }\end{array}$} & \multicolumn{2}{|c|}{$\begin{array}{c}35-44 \text { years }-55 \\
\text { years and more }\end{array}$} & \multicolumn{2}{|c|}{$\begin{array}{c}45-54 \text { years }-55 \\
\text { years and more }\end{array}$} \\
\hline $\mathrm{U}$ & $p$ & $\mathrm{U}$ & $p$ & $\mathrm{U}$ & $p$ & $\mathrm{U}$ & $p$ & $\mathrm{U}$ & $p$ & $\mathrm{U}$ & $p$ \\
\hline \multicolumn{12}{|c|}{ care for or illness of dependent family member } \\
\hline 139145 & 0.076 & 58839 & 0.000 & 20639 & 0.000 & 67607 & 0.000 & 23980 & 0.000 & 18559 & 0.000 \\
\hline \multicolumn{12}{|c|}{ own illness or injury (at or outside work) } \\
\hline 253185 & 0.130 & 176569 & 0.040 & 72951 & 0.000 & 199072 & 0.452 & 82593 & 0.000 & 60744 & 0.007 \\
\hline \multicolumn{12}{|c|}{ other reason for absence, which is not related to illness, injuries, or pressure } \\
\hline 49146 & 0.264 & 36161 & 0.010 & 20478 & 0.027 & 42118 & 0.110 & 23843 & 0.146 & 18686 & 0.839 \\
\hline \multicolumn{12}{|c|}{ TOTAL } \\
\hline 425953 & 0.275 & 248231 & 0.000 & 94692 & 0.000 & 270018 & 0.000 & 102967 & 0.000 & 76518 & 0.001 \\
\hline
\end{tabular}

$\mathrm{U}$ - value of Mann-Whitney test; $\mathrm{p}$ - statistical significance 


\subsection{Connection between field of work and sickness absenteeism in public administration}

In the research analysis, we checked whether there are statistically significant differences between respondents in relation to their field of work in the number of days and sets of sickness absenteeism in the past 12 months. Based on the data shown in Table 6, we found that officials (9.6 days on average) and professional-technical officials ( 9.5 days) were absent from work for the longest period of time, whereas officials in leading positions were absent for the shortest period of time (6.2 days). There are statistically significant differences between respondents about the number of days of sickness absenteeism in relation to the field of work, in the total number of days of sickness absence $\left(\chi^{2}=30.52 ; p<0.01\right)$, where officials and professional-technical personnel are statistically significantly more absent from work for a longer period of time than officials in leading positions, i.e. for more than three working days on average.

Statistically significant differences in the length of sickness absence have also appeared (Table 6) in sickness absence due to caring for or illness of a dependent family member $\left(\chi^{2}=30.55 ; \mathrm{p}<0.01\right)$, which is why officials and professional-technical public employees were on average absent from work at least 2.7 times as long as officials in leading positions. Officials and professional-technical personnel are statistically significantly absent from work longer than officials in leading positions due to their own illness or injury $\left(\chi^{2}=26.58 ; \mathrm{p}<0.01\right)$ and due to mental pressure and stress in the working environment $\left(\chi^{2}=7.92\right.$; $\mathrm{p}<0.05$ ).

Similarly to the analysis of days of sickness absenteeism by individual work areas, it is also evident from the analysis of the number of sets of sickness absence (Table 7) that officials and professional-technical personnel were statistically significantly several times more often absent from work than officials in the leading positions $\left(\chi^{2}=\right.$ $27.86 ; \mathrm{p}<0.01)$, where there were no statistically significant differences between the first two groups of interviewees. On average, professional-technical personnel were absent from work 1.63 times, and officials were only slightly less absent (1.58 times), while officials in the leading positions were statistically absent from work fewer times ( 0.9 times). The latter is true, both in sickness absenteeism due to caring for or illness of a family member $\left(\chi^{2}=25.44 ; p\right.$ $<0.01)$, as well as their own illness or injury $\left(\chi^{2}=27\right.$; $p<$ $0.01)$ and due to mental pressure and stress in the working environment $\left(\chi^{2}=7.53 ; p<0.05\right)$.

As was already pointed out between the groups of respondents employed in official and professional-technical positions, there are no statistically significant differences (Table 8), while the latter are shown in the comparison of both groups with a group of officials in leading positions.

Table 6: Descriptive statistics of the number of days of absence and the results of Kruskal-Wallis test by field of work and by individual reason for sickness absenteeism.

\begin{tabular}{|c|c|c|c|c|c|c|c|}
\hline & \multirow{2}{*}{ FIELD OF WORK } & \multirow{2}{*}{$\mathrm{N}$} & \multirow{2}{*}{$\mathrm{AM}$} & \multirow{2}{*}{ SD } & \multicolumn{3}{|c|}{ Kruskal-Wallis test } \\
\hline & & & & & $\chi^{2}$ & $\mathrm{df}$ & $p$ \\
\hline \multirow{3}{*}{$\begin{array}{l}\text { care for or illness of dependent } \\
\text { family member }\end{array}$} & РTP & 440 & 3.35 & 7.33 & \multirow{3}{*}{30.55} & \multirow{3}{*}{2} & \multirow{3}{*}{0.000} \\
\hline & OFF & 900 & 3.26 & 6.91 & & & \\
\hline & OMP & 214 & 1.21 & 3.64 & & & \\
\hline \multirow{3}{*}{$\begin{array}{l}\text { own illness or injury (at or outside } \\
\text { work) }\end{array}$} & PTP & 627 & 8.48 & 20.29 & \multirow{3}{*}{26.58} & \multirow{3}{*}{2} & \multirow{3}{*}{0.000} \\
\hline & OFF & 1335 & 8.65 & 20.63 & & & \\
\hline & OMP & 305 & 5.59 & 17.29 & & & \\
\hline \multirow{3}{*}{$\begin{array}{l}\text { mental pressure and stress in the } \\
\text { working environment (also due to } \\
\text { the behaviour of leaders) }\end{array}$} & PTP & 295 & 1.28 & 7.91 & \multirow{3}{*}{7.92} & \multirow{3}{*}{2} & \multirow{3}{*}{0.019} \\
\hline & OFF & 597 & 1.70 & 10.11 & & & \\
\hline & OMP & 173 & 0.84 & 9.18 & & & \\
\hline \multirow{3}{*}{$\begin{array}{l}\text { other reason for absence, which is } \\
\text { not related to illness, injuries, or } \\
\text { pressure }\end{array}$} & PTP & 284 & 0.72 & 5.41 & \multirow{3}{*}{1.85} & \multirow{3}{*}{2} & \multirow{3}{*}{0.396} \\
\hline & OFF & 579 & 0.77 & 4.65 & & & \\
\hline & OMP & 175 & 0.43 & 2.24 & & & \\
\hline \multirow{3}{*}{ TOTAL } & PTP & 776 & 9.51 & 20.07 & \multirow{3}{*}{30.52} & \multirow{3}{*}{2} & \multirow{3}{*}{0.000} \\
\hline & OFF & 1657 & 9.62 & 21.22 & & & \\
\hline & OMP & 354 & 6.17 & 17.55 & & & \\
\hline
\end{tabular}

$\mathrm{N}$ - number of answers; AM - arithmetic mean; SD - standard deviation; $\mathrm{df}$ - degrees of freedom; $\mathrm{p}$ - level of statistical significance; PTP - professional-technical personnel; OFF - officials; OMP - officials, managerial position 
Table 7: Descriptive statistics of the number of sets of absence and the results of Kruskal-Wallis test by field of work, and by an individual reason for temporary absence.

\begin{tabular}{|c|c|c|c|c|c|c|c|}
\hline & \multirow{2}{*}{$\begin{array}{l}\text { FIELD OF } \\
\text { WORK }\end{array}$} & \multirow{2}{*}{$\mathrm{N}$} & \multirow{2}{*}{$\mathrm{AM}$} & \multirow{2}{*}{ SD } & \multicolumn{3}{|c|}{ Kruskal-Wallis test } \\
\hline & & & & & $\chi^{2}$ & df & $p$ \\
\hline \multirow{3}{*}{ care for or illness of dependent family member } & PTP & 436 & 1.19 & 2.58 & \multirow{3}{*}{25.44} & \multirow{3}{*}{2} & \multirow{3}{*}{0.000} \\
\hline & OFF & 894 & 1.17 & 2.07 & & & \\
\hline & OMP & 215 & 0.51 & 1.16 & & & \\
\hline \multirow{3}{*}{ own illness or injury (at or outside work) } & PTP & 620 & 1.04 & 1.45 & \multirow{3}{*}{27.00} & \multirow{3}{*}{2} & \multirow{3}{*}{0.000} \\
\hline & OFF & 1318 & 1.03 & 1.37 & & & \\
\hline & OMP & 304 & 0.64 & 0.90 & & & \\
\hline \multirow{3}{*}{$\begin{array}{l}\text { mental pressure and stress in the working envi- } \\
\text { ronment (also due to the behaviour of leaders) }\end{array}$} & PTP & 295 & 0.21 & 1.04 & \multirow{3}{*}{7.53} & \multirow{3}{*}{2} & \multirow{3}{*}{0.023} \\
\hline & OFF & 596 & 0.17 & 0.63 & & & \\
\hline & OMP & 173 & 0.05 & 0.26 & & & \\
\hline \multirow{3}{*}{$\begin{array}{l}\text { other reason for absence, which is not related to } \\
\text { illness, injuries, or pressure }\end{array}$} & PTP & 284 & 0.11 & 0.58 & \multirow{3}{*}{1.71} & \multirow{3}{*}{2} & \multirow{3}{*}{0.425} \\
\hline & OFF & 577 & 0.19 & 0.91 & & & \\
\hline & OMP & 175 & 0.06 & 0.30 & & & \\
\hline \multirow{3}{*}{ TOTAL } & PTP & 772 & 1.63 & 2.75 & \multirow{3}{*}{27.86} & \multirow{3}{*}{2} & \multirow{3}{*}{0.000} \\
\hline & OFF & 1650 & 1.58 & 2.29 & & & \\
\hline & OMP & 354 & 0.91 & 1.33 & & & \\
\hline
\end{tabular}

$\mathrm{N}$ - number of answers; AM - arithmetic mean; SD - standard deviation; df - Degrees of Freedom; $\mathrm{p}$ - level of statistical significance; PTP - professional-technical personnel; OFF - officials; OMP - officials, managerial position

Table 8: A series of post-hoc tests (Mann-Whitney U test) between pairs of fields of work, in relation to the number of days and the number of sets of absence.

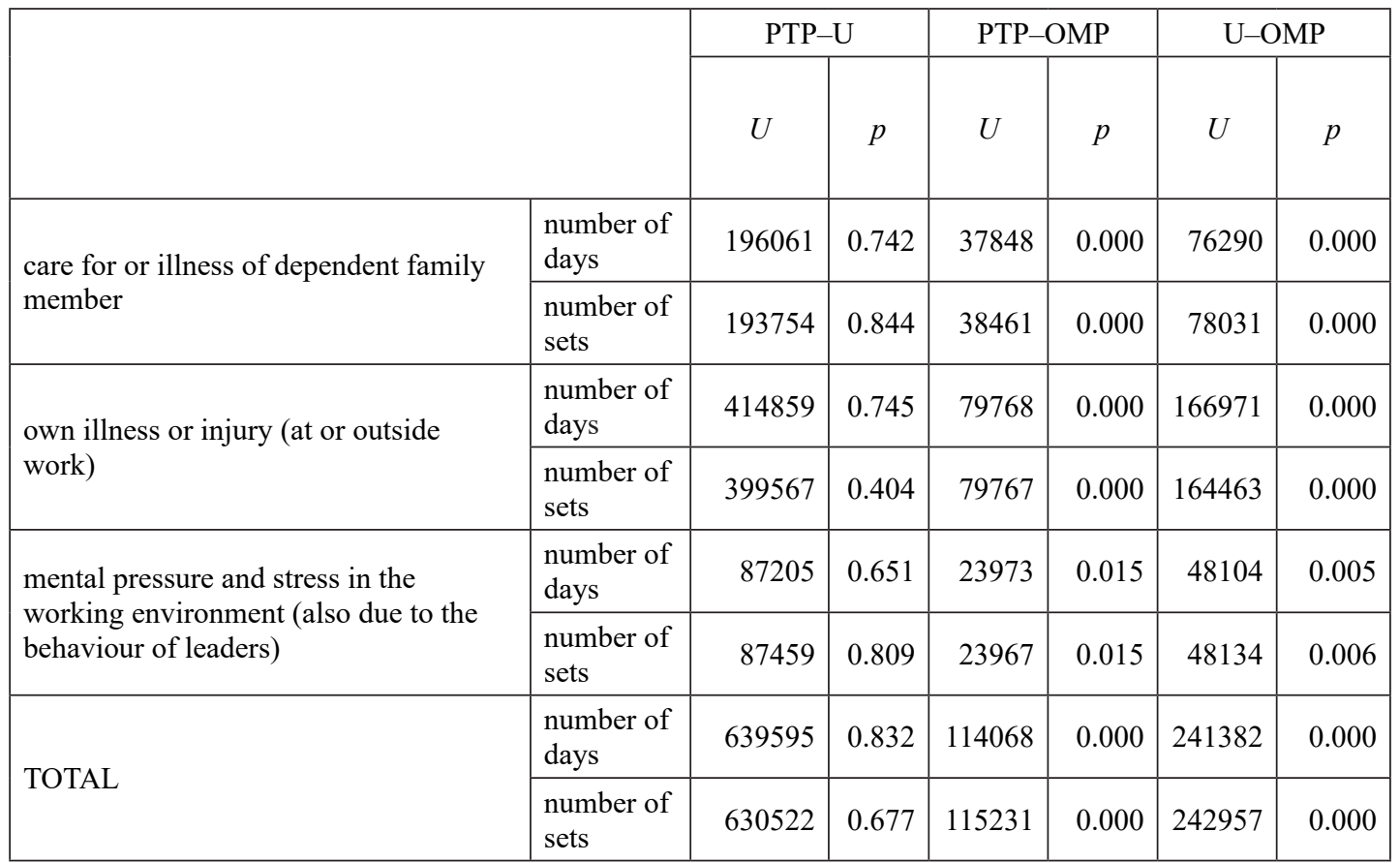

U - value of Mann-Whitney test; $\mathrm{p}$ - statistical significance; PTP - professional-technical personnel; OMP - officials, managerial position 


\section{Discussion}

In the framework of studying, and the research that has been carried out, it was discovered that there is a statistically significant connection on sickness absenteeism in public administration with years of service, as well as the field of work of employees. We discovered that those with fewer years of service, measured in the number of days, have less sickness absence than those with more years of service. The last result of the research is similar to the findings of the research that was carried out in the Italian public sector, and where it was established that sickness absenteeism increases with the seniority of employees (De Paola, Scoppa and Pupo, 2014). The reverse trend related to the number of days of absence of employees from work can be detected when measuring sickness absenteeism in the number of sets (how many times) of sickness absenteeism. At this point, we discovered that by increasing seniority, the number of sets of sickness absence decreases. This means that those with fewer years of service are more often absent from work due to sickness than those with more years of service.

In this framework, it is reasonable to explain that Lokke Nielsen (2008, p. 1334) notes that if sickness absenteeism is the result of dissatisfaction with the work situation, employees with higher seniority may face fewer career opportunities and fewer possibilities for employment in another organisation. The latter may lead to dissatisfaction, and a consequence of that is also their higher rate of sickness absenteeism.

In case we consider the context of this explanation of the results of our research about the connection between sickness absenteeism and years of service, the results in public administration could also be interpreted in a way that with employees with more years of service, there is an occurrence of possible disappointment or limited possibilities for promotion, in relation to the career system in public administration - a consequence of that is also their dissatisfaction, which can be seen in an increased number of sickness absences.

Explaining the research results about the connection between seniority and sickness absenteeism can also be interpreted in such manner that it is sensible to understand seniority in close connection with the age of employees. Originating from that, a result of this kind, if it is also explained through age, meets the expectations. Evans and Palmer (2000, p. 21) explain that it is typical of the young that they are absent more often, but for a shorter period of time than older employees, and the older ones are less absent in terms of frequency; however, within individual absences they are absent for more days than the young, in particularly after age 50 . At the same time, we can understand the result of the connection between years of service and sickness absenteeism through the prism of health and well-being of employees, and the ability of the human or- ganism to become empowered or recover, because when growing older, the human organism needs more time for recovery.

There is also an interesting research result in the field of the connection between the field of work of employees in the organisation and sickness absenteeism in public administration. We discovered that there is a statistically significant connection, i.e. officials and the professional-technical personnel are statistically for a longer time and more often absent from work than officials in leading positions (leading personnel). This means that heads are absent for fewer days and less often than employees that are being led by them. This can be understood as beneficial and encouraging if the results are interpreted from the viewpoint of "an example and culture of work by leading personnel". The leading personnel (are supposed to) represent an example for cultural behaviour of employees, and even culture (ethics) that is present in the area of sickness absenteeism and is very important, because it was discovered that in cases where employees perceive that the leading personnel are missing from work (even unjustifiably), they quickly take such a manner of behaviour or adopt such practices for themselves. The result that the officials in leading positions are absent from work fewer times than officials and professional-technical public employees can be understood through the spectre of greater responsibility and diligence of the leading personnel, in order to regulate things in the work collective. The easiest way to arrange the latter is if the leading personnel are present in the working environment, because this will enable them to solve any problems in the working environment quickly.

It is interesting that officials and professional-technical public employees are absent from work at least 2.7 times longer than officials in leading positions, due to caring for or illness of a dependent family member. These research results can be understood and interpreted in the direction that officials and professional-technical public employees decide faster and easier for absence from work to care for or support family members than the leading personnel. These findings of our research we can understand in a way as Kozjek and Ferjan (2015, p. 13) explain in their research. The results in their research show that participants on managerial workplaces evaluated more highly:

- the possibilities of an individual to access infrastructure for the basic health needs of safety at workplace,

- the level of protection of an individual from large changes in working conditions by the current employer,

- the possibilities of an individual to have safe working conditions, which also enable well-being in the workplace, the possibilities of an individual to have work-life balance, understanding enabling an individual to satisfy family needs,

- the possibilities of an individual to have resources for a decent life (such as income, the regulation of 
minimum wage),

- the possibilities of an individual to have opportunities for wages coordination and indexation.

In the context of understanding the results of the performed research, we have established that, based on self-assessment of the respondents of the research, there is a prevailing state in public administration that, in relation to seniority, officials in the leading positions are absent from work fewer days and fewer times than other public employees.

\section{Conclusion}

In the working environment, employees and employers face different challenges. Challenges are usually even harder if there are factors in the working environment that can directly or indirectly interrupt or undermine work activities. One of those phenomena is sickness absenteeism. Even sickness absenteeism is often understood as a negative occurrence, and it is reasonable to understand and to detect important messages for employees, employers, and the state in this phenomenon. With the occurrence of sickness absenteeism, employers can receive important messages about whether they should engage more in certain areas or sort things out. The latter means that, in such cases, it is reasonable for the employer to make a so-called "self-reflection" of the state in the working environment, and adopt measures to improve the future state. It is interesting that in some cases, employees also decide for a sickness absence because they cannot stand the working environment anymore, and need to retreat into a healthier and safer environment to revitalise and empower themselves, before returning to the working process. The reasons for sickness absenteeism vary and should be explained as such, taking into consideration that the factors for absence from work are very much intertwined.

Sickness absenteeism in public administration in Slovenia is, according to statistical indicators, recorded in a higher percentage ( $7.1 \%$ in 2018) than the percentage that applies for the whole of Slovenia (4.5\% in 2018), and that was one of the reasons why we conducted this research in Slovenian public administration. The purpose of this research was to find out whether there is the connection between number of years of service, the field of work (work position), and sickness absenteeism in public administration. The results of the research confirmed the preliminary assumptions that it will be possible to confirm these influences. It was indeed established that there is a statistically significant influence between sickness absenteeism, years of service, and field of work (work position) of employees in public administration. Those with fewer years of service are absent from work for less time than those with more years of service. Employees in leading official positions are absent from work less often and for a fewer number of days than the group of officials and professional-technical public employees.

The research represents one of the first presentations of its kind about the connection between some demographic factors of employees in public administration and sickness absenteeism, by individual reasons in public administration in Slovenia. Such findings of our research, which are presented in the article, represent an important contribution to understanding certain correlations and characteristics that are related to sickness absenteeism in public administration. At this point, it should not be overlooked that such findings are important, also because we identified some (socio)demographic characteristics of employees, and gained an insight into certain (personal and business) characteristics of employees in public administration that are most often absent from work. The latter represents a contribution to the identification of the groups of employees, on which attention should be placed to reduce the proportion of sickness absence. This mainly involves employees who do not occupy managerial posts, and employees with a greater length of service (older employees). Given that in recent years, increased attention has been devoted to the management of older employees, the results of our research also need to be understood in this respect; moreover, in order to reduce sickness absenteeism in public administration, solutions should be sought, with ongoing measures in the field of care for older employees (e.g. measures to improve the health and vitality of older employees, fair treatment and fair appreciation of older employees, relationships between generations in the work environment, etc.). Ybema et al. (2016, p. 645) explain that it is important for organizations that older employees remain healthy. If organizations treat their employees in a just way this signals that all employees are valued, which may improve the health of employees and the functioning of the organization. The study by Ybema et al. (2016) suggests that organizations may reduce sickness absence among their older employees by investments. They also suggest that a fair treatment and a fair appreciation of older employees are such an important solutions. A fair treatment of employees can prevent productivity loss and sickness absence, whereas lack of appreciation and unfair procedures may lead to productivity loss and sickness absence. Relationships at work may erode as a result of (long term) sickness absence. This could lead to a vicious circle in which lower organizational justice further increases sickness absence of older employees (Ybema, Meer, \& Leijten, 2016, p. 653). These should also be considered by the state and HR departments by drawing up measures to reduce sickness absenteeism of older employees in public administration.

Sickness absenteeism in connection with officials and professional-technical public employees in public administration could be reduced by assigning them greater responsibility related to work and activities in the work environment and provide them better leaders and conditions 
for satisfaction in the workplace. The study of Van Dierendonc (2002) suggests that giving employees responsibilities reduces sickness absenteeism. The leaders of employees have an important role also in connection with sickness absence. Boudreau et al. (1993) showed in their study that employees who are less satisfied with their supervisor tend to be absent more. Elshout et al. (2013) suggest that organizations and employees may have benefits from the leaders who have the transformational leadership style. This may result in better employee satisfaction and lower sickness absenteeism. The transformational leadership style is also highly recommended by Van Dierendonc (2002). According to Zhu et al. (2005) specific human resource management practices can have a positive effect on employee performance, motivation, skills, abilities, and knowledge, thus reducing sickness absenteeism. One of the key factors in creating this effect is leader with his owen leadership style. Elshout et al. (2013) explain that employees who are more satisfied with their job and their supervisor will be more committed to the organization and call in sick less often. Munch-Hansen et al. (2009) found a decrease in average sickness absence with increasing satisfaction with psychosocial work conditions. Kozjek and Ferjan (2015, p. 19) explain that employees on managerial workplaces are enabled functional flexibility, more often than those on non-managerial workplaces, which is often associated with better opportunities in regarding economic security (better payment), workplace security, job skills security and combination security. Therefore, organizations need to be aware that their employees have good opportunities with regard to economic, income, workplace, work and combination se $\neg$ curity.

The results of our survey show just a few aspects of how field of work and years of service have an effect on sickness absenteeism in public administration. Nevertheless, numerous other factors (e.g. gender, age, relationship between employees and managerial staff, working conditions, health of employees, etc.), which affect the sound understanding of sickness absenteeism, need to be considered in understanding sickness absenteeism. In drawing up and implementing the survey in public administration, we encountered some limitations and difficulties. The latter relate mainly to the sensitivity of the area we have studied, and the large number of surveys conducted in public administration in Slovenia in recent years. However, we are extremely pleased with the response of the participants. The limitations also relate to the fact that the survey was only conducted in public administration, and not in the whole public sector or in the private sector. To this end, it would be reasonable to extend the survey to the whole public and private sector, and also abroad, over the coming years. By expanding the survey to include employees in the whole public and private sector, we would gain an in-depth insight into the understanding of sickness absence. Moreover, we could broaden the survey by posing questions to employees with more than 20 years of service, relating to the way the employers care for them in the work environment, and the measures implemented in connection with employee health care. As regards the employees with less than 20 years of service, it would be worth examining how they were introduced to the work environment, and what is the quality of their relationship with managerial staff and other employees.

\section{Literature}

Allebeck, P., \& Mastekaasa, A. (2004). Causes of sickness absence: research approaches and explanatory models. Scandinavian Journal Public Health, 32 (63), 36-43. http://doi.org/10.1080/14034950410021835

Bal P.M, de Lange AH, \& Ybema, J,F, (2011). Age and trust as moderators in the relation between procedural justice and turnover: A large-scale longitudinal study. Applied Psychology: International Review, 60, 66-86. https://doi.org/10.1111/j.1464-0597.2010.00427.x

Buzeti, J., Stare, J., Klun, M., \& Kotnik, Ž. (2016). The Impact of Leader's Temperament on Work Absence. Transylvanian Review of Administrative Sciences, Special Issue 2016, 23-37.

Buzeti, J., Bilban, M., \& Stare, J. (2015). Correlation between sickness absenteeism and temperament of employees in the public administration«. Mednarodna revija za javno upravo, 13(3-4), 27-66. http://doi.org/10.17573/ipar.2016.2-3.07

Buzeti, J. (2015). Povezanost vedenja vodij z začasno odsotnostjo zaposlenih $\mathrm{z}$ dela $\mathrm{v}$ javni upravi. [The connection between leader behavior and temporary employee absence from work in public administration]. Doctoral dissertation: Faculty of Administration of University of Ljubljana, Slovenia.

Boudreau, C.A., Christian, W.P., \& Thibadeau, S.F. (1993). Reducing Absenteeism in a Human Service Setting. Journal of Organizational Behavior Management. 13(2), 37-50. http://doi.org/10.1300/J075v13n02_04

Coffey, M., Dugdill, L., \& Tattersall, A. (2009). Working in the Public Sector - A Case Study of Social Services. Journal of Social Work, 9(4), 420-442. http://doi.org/10.1177/1468017309342177

De Paola, M., Scoppa, V. \& Pupo, V. (2014). Absenteeism in the Italian Public Sector: The Effects of Changes in Sick Leave Policy. Journal of Labor Economics. 32(2), 337-360. http://doi.org/10.1086/674986

Elshout, R., Sherp, E., \& Van Der Feltz-Cornelis, C. (2013). Understanding the link between leadrship style, employee satisfaction, and absenteeism: a mixed methods design study in a mental health care institution. Neuropsychiatric Disease and Treatment, 13(9), 823-837. http://doi.org/10.2147/NDT.S43755

Evans, A., \&Palmer, S. (2000). From absence to attendance. London: Chartered Institute of Personnel and Development - CIPD House.

Fitzgerald, S., Kirby, A., Murphy, A., \& Fiona Geaney (2016). Obesity, diet quality and absenteeism in a work- 
ing population. Public Health Nutrition, 19(18), 32873295. http://doi.org/10.1017/S1368980016001269

Forte, A., \& Nicola, S. (2017). Strategies for Reducing Employee Absenteeism for a Sustainable Future: A Bermuda Perspective. Doctoral dissertations, Walden University.

Halbesleben, J., Whitman, M. V., \& Crawford, W. S. (2014). A dialectical theory of the decision to go to work: Bringing together absenteeism and presenteeism. Human Resource Management Review, 24, 177192. http://doi.org/10.1016/j.hrmr.2013.09.001

Hum Wee, L., Lay Ling Yeap, L., Mei Hsien Chan, C., Eiin Wong, J., Aini Jamil, N., Swarna Nantha, Y., \& Sin Siau, C. (2019). Anteceding factors predicting absenteeism and presenteeism in urban area in Malaysia. BMC Public Health, 19(4). http://doi.org/10.1186/s12889-019-6860-8

Kozjek, T., Ferjan, M. (2015). Organizational Flexibility, Employee Security, and Organizational Efficiency - a Case Study of Slovenian Public and Private Sector Organizations. Organizacija. 48, 3-21. http://doi.org/10.1515/orga-2015-0001

Kralj, A., Sedmak, M. Kotnik, V., Medica, K., Sekloča, P., Medarič, Z., Simčič, B. (2013). Analiza stanja psihosocialnih tveganj na delovnih mestih $\mathrm{v}$ mikro, malih in srednje velikih podjetjih [Analysis of psychosocial risks in workplaces in micro, small and medium-sized enterprises]. Retrieved December 28, 2019, from http://www.ir-rs.si/f/docs/Razvojni projekti/Studija_MSP.pdf

Løkke, A.K. (2014) Past absence as a predictor of present absence: the case of a large Danish municipality. The International Journal of Human Resource Management, 25(9), 1267-1280. http://doi.org/10.1080/09585192.2013.831112

Løkke Nielsen, A.K. (2008). Determinants of absenteeism in public organizations: a unit-level analysis of work absence in a large Danish municipality. The International Journal of Human Resource Management, 19(7), 13301348. http://doi.org/10.1080/09585190802110158

Løkke, A.K, Eskildsen, J.K., \& Jensen, T.W. (2007). Absenteeism in the Nordic countries. Employee Relations, 29(1), 16-29. http://doi.org/10.1108/01425450710714450

Løkke, A.K., \& Krøtel, S.M.L. (2019). Performance evaluations of leadership quality and public sector leaders' absenteeism. Public Management Review, 1-22. http://doi.org/10.1080/14719037.2019.1638441

Łyszczarz, B. (2019). Indirect costs and incidence of caregivers'short-term absenteeism in Poland, 2006-2016. BMC Public Health, 19(1). http://doi.org/10.1186/s12889-019-6952

Munch-Hansen, T., Wieclaw, J., Agerbo, E., Westergaard-Nielsen, N., Rosenkilde, M., \& Bonde, J.P. (2009). Sickness absence and workplace levels of satisfaction with psychosocial work conditions at public service workplaces. American Journal of Industrial Medicine. 52, 153-161. http://doi.org/10.1002/ajim.20657

NIJZ (Nacionalni inštitut za javno zdravje). (2013-2018). Sickness absence indicators. Retrieved July 28, 2019, from https://podatki.nijz.si/Table.aspx?layout=tableViewLayout2\&px_tableid=BS_TB4.px\&px_path=NIJZ\%20podatkovni\%20portal_1\%20 Zdravstveno\%20stanje $\% 20$ prebivalstva $07 \overline{\%} 0 \mathrm{Bol}-$ ni $\%$ c5\%alki\%20stale $\%$ c5\%be\&px language $=$ sl\&px $\mathrm{db}=\mathrm{NIJZ} \% 20$ podatkovni\%20portal \&rxid=06dff5f2bea1-4a86-8393-1f09e93f72f6

NIJZ (Nacionalni inštitut za javno zdravje) (2019). Sickness absence indicators. Retrieved December 21, 2019, from https://podatki.nijz.si/Table.aspx?layout=tableViewLayout2\&px_tableid=BS_TB4.px$\& p x$ path $=$ NIJZ $\% 20$ podatkovni\%20portal $1 \% 20$ Zdravstveno\%20stanje $\% 20$ prebivalstva $07 \% 20 \mathrm{Bol}-$ ni $\%$ c5\%a1ki\%20stale $\%$ c5\%be\&px language $=$ sl\&px $\mathrm{db}=$ NIJZ\%20podatkovni\%20portal\&rxid=e $1 \mathrm{c} 5 \mathrm{a} 200-$ d974-476b-8691-3a1169b46a3b

Nguyen, H., Groth, M., \& Johnson, A. (2013). When the going gets tough, the tough keep working: Impact of emotional labor on absenteeism. Journal of Management, 42, 615-643.

http://doi.org/10.1177/0149206313490026

Nielsen, K. \& Daniels, K. (2016). The relationship between transformational leadership and follower sickness absence: the role of presenteeism. Work \& Stress - An International Journal of Work, Health \& Organisations, 30 (2), 193-208.

http://doi.org/10.1080/02678373.2016.1170736

Ones, D.S., Viswesvaran, C., \& Schmidt, F.L. (2003). Personality and absenteeism - A meta-analysis of integrity tests. European Journal of Personality, 17(2), 19-39. http://doi.org/10.1002/per.487

Patton, E., \& Johns, G. (2012). Context and the social representation of absenteeism: Absence in the popular press and in academic research. Human Relations, 65, 217-240. http://doi.org/10.1177/0018726711428819

Pfeifer, C. (2010). Impact of wages and job levels on worker absenteeism. International Journal of Manpower, 31(1), 59-72. http://doi.org/10.1108/01437721011031694

Rhodes, S.R., \& Steers, R.M. (1990). Managing employee absenteeism. Boston: Addison-Wesley Publishing Company.

Rosenblatt, Z., Shapira-Lishchinsky, O. \& Shirom, Arie (2010). Absenteeism in Israeli schoolteachers: An organizational ethics perspective. Human Resource Management Review, 20, 247-259. http://doi.org/10.1016/j.hrmr.2009.08.006

Schouten, L.S., Bültmann, U., Heymans, M.W., Joling, C.I., Twisk, J., \& Roelen, C. (2016). Shortened version of the work ability index to identify workers at risk of long-term sickness absence. European Journal of Public Health, 26(2), 301-305.

http://doi.org/https://doi.org/10.1093/eurpub/ckv198

Schmid, J.A., Jarczok, M.N., Sonntag, D., Herr, R.M., Fischer, J.E. \& Schmidt, B. (2017). Associations between Supportive Leadership Behavior and the Costs 
of Absenteeism and Presenteeism: An Epidemiological and Economic Approach. Journal of Occupational \& Environmental Medicine, 59 (2), 141-147. http://doi.org/10.1097/JOM.0000000000000919

Shapira-Lishchinsky, O., \& Raftar-Ozery, T. (2016). Leadership, absenteeism acceptance, and ethical climate as predictors of teachers' absence and citizenship behaviors. Educational Management Administration \& Leadership, 1-20.

http://doi.org/10.1177/1741143216665841

Tičar, B., \& Rakar, I. (2011). Pravo javnega sektorja [Public sector law]. Inštitut za lokalno samoupravo in javna naročila, Maribor.

Toth, M. (1999). Kako se Evropa spopada z zdravstvenim absentizmom [How Europe copes with health absenteeism]. Evrobilten, 6, 20-21.

Public Employees Act (Official Gazette of the Republic of Slovenia, no. 95/09, 110/02, 02/04, 23/05, 35/05 - upb1, 62/05, 75/05, 113/05, 32/06 - upb2, 33/07, 63/07-upb3, 65/08, 40/12)

Van Dierendonck, D., LeBlanc, P.M., van Breukelen, W. (2002). Supervisory behavior, reciprocity and subordinate absenteeism. Leadership and Organization Development Journal, 23(2), 84-92.

http://doi.org/10.1108/01437730210419215
Ybema, J.F., Meer, L., \& Leijten, F.R.M. (2016). Longitudinal Relationships between Organizational Justice, Productivity Loss, and Sickness Absence among Older Employees. International Journal of Behavioral Medicine, 23, 645-654. http://doi.org/10.1007/s12529-016-9546-y

Zhu, W., Chew, I.K.H., Spangler, W.D. (2005). CEO transformational leadership and organizational outcomes: The mediating role of human-capital-enhancing human resource management. The Leadership Quarterly, 16, 39-52. http://doi.org/10.1016/j.leaqua.2004.06.001

Jernej Buzeti, is an assistant professor at the Faculty of Public Administration, University of Ljubljana, where he successfully defended a doctoral dissertation titled "The connection between leader behaviour and temporary employee absence from work in public administration". He is also a Vice Dean for knowledge transfer at the faculty. His field of research relates to leadership and human resource management or the organisation of the public sector. He is also involved in preparing and conducting practical classes and seminars. 


\section{Appendix: Questionnaire}

General (demographic) data

Gender: • male • female

Education:

- Secondary education

- University education

- Tertiary education

- Residency

- Tertiary education (former)

- Bachelor

- Master (former)

- University education (former) - Doctorate

Year of birth:

Organisation of employment:

- State administration

- Local administration

- Holders of public authorities

Duration of employment in the organisation of current employment: years, months

Work area:

Sickness absence:

1. How many DAYS and HOW MANY TIMES have you been absent in the past 12 months due to taking care of a dependent family member?

a. Number of DAYS:

b. Number of OCCASIONS:

2. How many DAYS and HOW MANY TIMES have you been absent in the past 12 months due to illness or injury (work or non-work related)?

a. Number of DAYS:

b. Number of OCCASIONS:

3. How many DAYS and HOW MANY TIMES have you been absent in the past 12 months due to pressure or stress in the working environment (also due to leader behaviour)

a. Number of DAYS:

b. Number of OCCASIONS:

4. How many DAYS and HOW MANY TIMES have you been absent in the past 12 months due to reasons not related to sickness, injury, pressure, stress, etc.?

a. Number of DAYS:

b. Number of OCCASIONS:

5. In the past 12 months, have you been temporarily absent from work (due to sickness, injury, family member care) despite being able to carry out work tasks?
a. YES

b. $\quad \mathrm{NO}$

6. In the past 12 months, have you performed your work tasks despite being ill or injured (and thus being eligible for taking sick leave) because you felt and knew that you must carry out these tasks?

a. YES

b. NO 